\title{
A Comparison between Public School Teachers and Remedial Class Teachers' Attitude toward Physics Learning
}

\author{
Yubin $\mathrm{Xu}^{1}$, Zixin $\mathrm{Xiao}^{1}$, and Guangtian $\mathrm{Zhu}^{1{ }^{1 *}}$ \\ ${ }^{1}$ College of Teacher Education, East China Normal University, Shanghai 200062, China \\ *Corresponding Author: gtzhu@phy.ecnu.edu.cn
}

(Received: 04/28/2021; Accepted: 09/23/2021; Published: 10/30/2021)

DOI: https://doi.org/10.37906/real.2021.4

\begin{abstract}
Many students in east-Asian countries study physics in not only public schools but also remedial classes. We survey 42 school teachers and 41 remedial class teachers with the Colorado Learning Attitudes about Science Survey (CLASS). In this paper, we discuss the CLASS results from the two types of physics teachers. We also demonstrate the possible factors that attribute to the school teachers and remedial class teachers' significant different attitudes toward problem-solving confidence.
\end{abstract}

Keywords: Physics learning attitudes; School teachers; Remedial class teachers; Teacher training

\section{Introduction}

The attitude in physics learning is of great significance to physics teachers, since it is not only closely related to teaching quality, but also has an important influence on the conception of teaching(Ping Zhang,Weirong Liu, Yanli Li \& Xiaodi Yang, 2014). With the vigorous development of training institutions, many students will actively participate in remedial classes (or cram schools) in addition to their in-class study. To some extent, the remedial classes satisfy students' needs for personalized education and makes vital contributions to the construction of a diversified education system (Fang Fang\&Binlin Zhong, 2014). Compared to school teachers, remedial class teachers pay more attention to the efficiency of short-term learning and the practicality of problem-solving methods, which could effectively improve their students' test scores(Yue Gu, 2016; Ying Liu, 2016). The training objectives and teaching environment of the two kinds of teachers are quite different. Hence, we are interested in whether school teachers and remedial class teachers hold different attitudes about physics learning.

In our study, we used the Colorado Learning Attitudes about Science Survey (CLASS) to test the two types of teachers, hoping to find out the similarities and differences of the two kinds of teachers' physics learning attitudes. The CLASS can assess teachers' understanding of physics knowledge and attitude towards physics learning. It is a relatively common survey of learning attitude in the world and has been widely used in teaching practice at present (Mirko Marušić \& Josip Sliško, 2012). There are 42 questions in this survey, and five-point Likert score is adopted. The questions were divided into eight categories: A. Real world connection; B. Personal interest; C. Sense making; D. Conceptual connections; E. Applied conceptual understanding; F. Problem-solving general; G. Problem-solving confidence and H. Problemsolving sophistication(W. K. Adams,K. K. Perkins,N. S. Podolefsky,... \& C. E. Wieman, 2006). Each category 
contains several questions. The purpose of CLASS is to measure participants' self-reported beliefs about physics and how closely these beliefs about physics align with experts' beliefs.

In this study, we selected 42 school teachers and 41 remedial class teachers to participate in the CLASS test. The teachers who took part in this test had 3-5 years of teaching experience in high school physics. The CLASS questionnaires were distributed and collected online at the end of 2019-2020 spring semester.

\section{Data Analysis}

As is shown in Table 1, the overall scores of the CLASS for the school teachers was $74 \%$ (the percentage of participants who agreed with the experts), while the overall scores for the remedial class teachers was 73\%. We used SPSS to conduct differential detection on the overall scores of the two types of teachers, and the significance coefficient showed that there was no significant difference between the two types of teachers.

Table 1. The overall scores of the CLASS for the two types of teachers

\begin{tabular}{|l|c|c|c|c|c|c|}
\hline & $\begin{array}{l}\text { Sample } \\
\text { Size }\end{array}$ & Minimum & Maximum & $\begin{array}{l}\text { Average } \\
\text { Scores }\end{array}$ & Variance & $\begin{array}{l}\text { Significance } \\
\text { Coefficient }\end{array}$ \\
\cline { 1 - 6 } $\begin{array}{l}\text { School } \\
\text { teachers }\end{array}$ & 42 & $53 \%$ & $94 \%$ & $74 \%$ & 0.11 & 0.913 \\
\cline { 1 - 5 } $\begin{array}{l}\text { Remedial } \\
\text { teachers }\end{array}$ & 41 & $42 \%$ & $89 \%$ & $73 \%$ & 0.10 & \\
\hline
\end{tabular}

The scores of eight categories for the two types of teachers

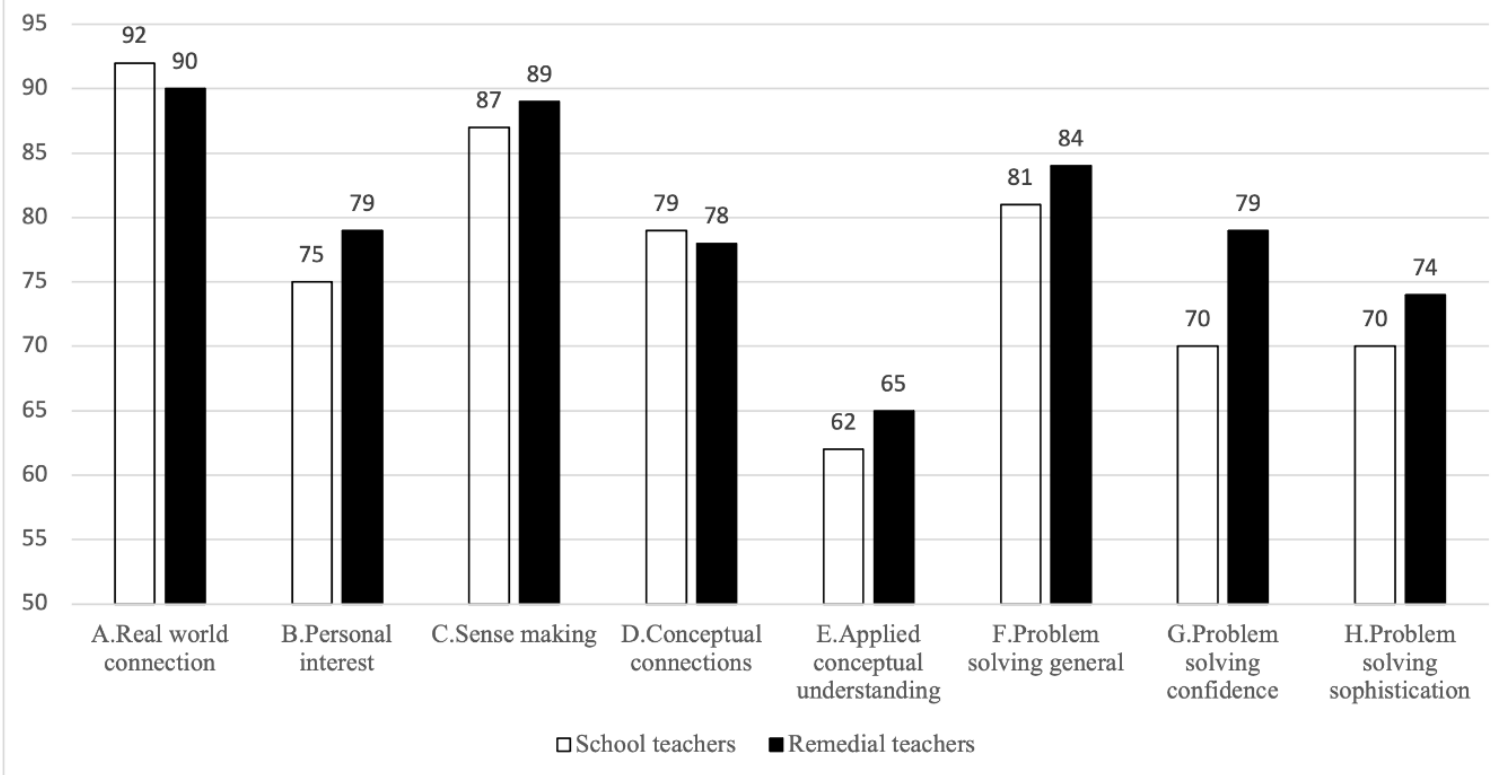

Figure 1. The scores of eight categories for the two types of teachers 
Table 2. The significance coefficient of eight categories scores for the two types of teachers

\begin{tabular}{|l|c|c|c|c|c|c|c|c|}
\hline & A & B & C & D & E & F & G & H \\
\hline $\begin{array}{l}\text { Significance } \\
\text { Coefficient }\end{array}$ & 0.881 & 0.463 & 0.698 & 0.879 & 0.553 & 0.468 & 0.017 & 0.750 \\
\hline
\end{tabular}

We compare the school teachers and the remedial class teachers' average scores in the eight categories of CLASS. Figure 1 shows the score comparison of eight categories in CLASS, and Table 2 shows the calculated significance coefficient. A-H in the Table 2 represents the eight categories corresponding to Figure 1. The only significant difference lies in the category G, i.e., the category of problem-solving confidence. The significance coefficient of the two kinds of teachers in $\mathrm{G}$ category (problem-solving confidence) is $0.017(<0.05)$. The result suggests that the remedial class teachers are more confident in problem solving.

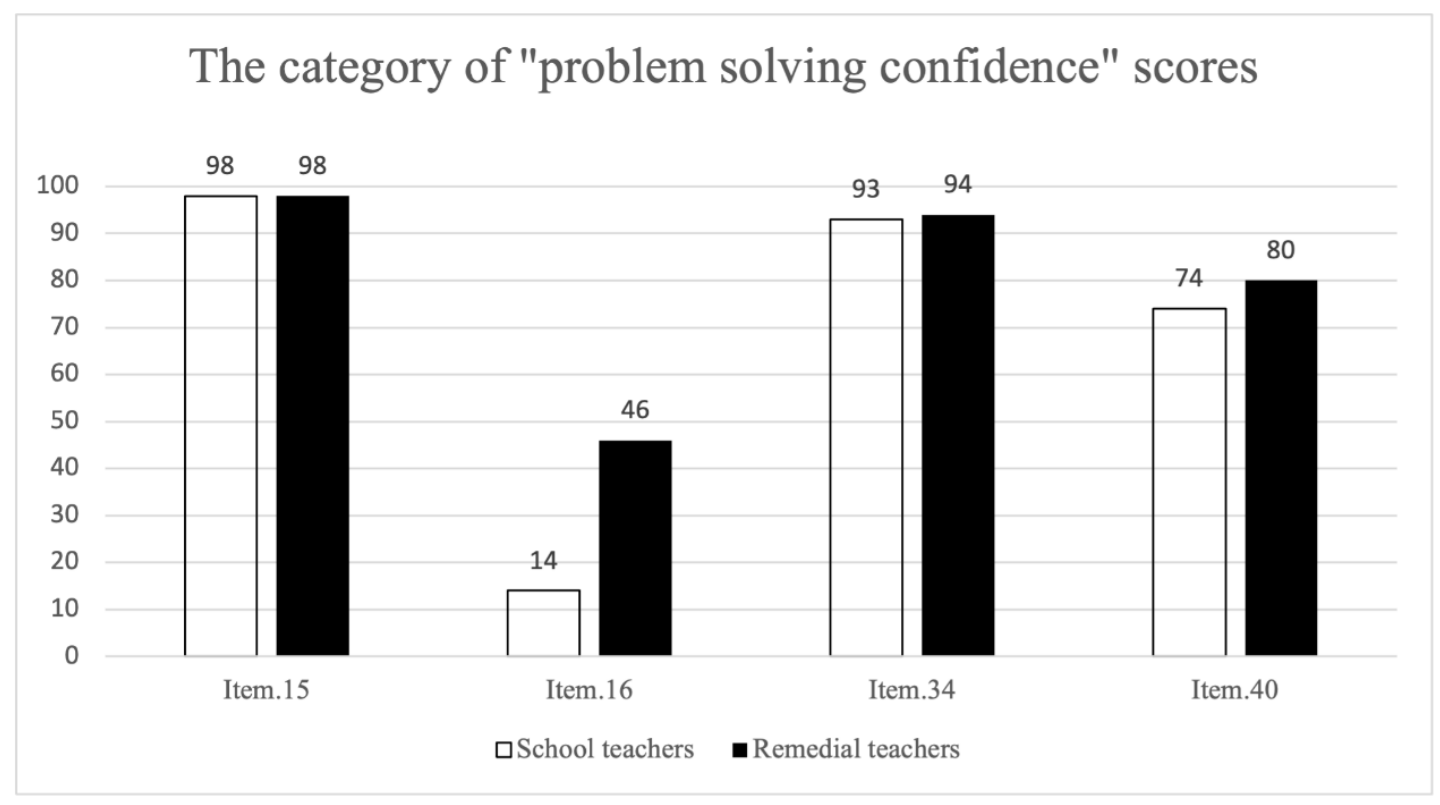

Figure 2. The category of "problem solving confidence" scores

We further analyzed the four questions (item 15, 16, 34, 40) in the category of problem-solving confidence. The scores of questions on item 15, 34 and 40 for the two types of teachers were basically the same, and the number of participants who agreed with the experts' views accounted for more than $74 \%$. However, there was a big difference between the two types of teachers' responses to item 16. Item 16 askes the participants whether they agree with the statement that "Nearly everyone is capable of understanding physics if they work at it". The proportion of the two kinds of teachers who agree with the experts is less than $50 \%$, since most of physics teachers would believe students' faculty of understanding play a much more important role than hard work. However, based on these lower rates in item 16, the remedial class teachers' number is three times higher than school teachers. A greater portion of remedial class teachers tend to agree with the experts' opinion that most students can learn physics well through hard working. 


\section{Discussion}

The data of CLASS showed that more remedial class teachers believe that "nearly everyone is capable of understanding physics if they work at it". In this regard, we interviewed school teachers and remedial class teachers in order to analyze the differences in the characteristics of students and teaching design of the two types of teachers.

\subsection{Different features of students in public schools and remedial classes}

The student groups in public schools and remedial classes have different features. In order to compare the different academic background of students in public schools and remedial classes, we collected the statistics of a midterm examination from a public school and a remedial class in the same district. The midterm exam is designed and administered by the Education Bureau of the district. All students in that district have taken the same test so that their scores are comparable.

The scores of students in the remedial class are collected by the remedial class teacher. The scores of students in school are obtained from the transcripts of three different classes in a public school. In order to provide appropriate teaching strategies accommodating to different students, the public school arranges students into three types of classes. Students with outstanding academic performance are assigned to Class A (also called the "Rocket Class" in many Chinese public high schools). The goal of the students in Class A is to be accepted into top universities so that these students usually receive rigorous training with difficult problems in physics (and other subjects). Students with average academic performance are assigned to Class B and their goal is to catch up with the students in Class A. Students with below-average academic performance are assigned to Class $\mathrm{C}$. The fundamental academic knowledge and skills are emphasized in Class $\mathrm{C}$ in order to help the students to pass the college-entrance exams. The statistical results of the different classes are shown in Table 3.

Table 3 Midterm examination scores of students in a remedial class and a public school. "Excellence rate" represents the percentage of students scored above 90 (full score is 100). "Passing rate" represents the percentage of students scored above 60 .

\begin{tabular}{|l|c|c|c|c|c|}
\hline Class type & $\begin{array}{l}\text { Sample } \\
\text { Size }\end{array}$ & $\begin{array}{l}\text { Average } \\
\text { Scores }\end{array}$ & $\begin{array}{l}\text { Standard } \\
\text { Deviation }\end{array}$ & $\begin{array}{l}\text { Excellence } \\
\text { Rate }\end{array}$ & Passing Rate \\
\hline Remedial Class & 38 & 72.9 & 9.73 & $2.6 \%$ & $92.1 \%$ \\
\hline School Class A & 46 & 79.5 & 11.3 & $15.2 \%$ & $93.5 \%$ \\
\hline School Class B & 48 & 71.2 & 10.7 & $2.1 \%$ & $83.3 \%$ \\
\hline School Class C & 45 & 52.5 & 16.1 & $0 \%$ & $33.3 \%$ \\
\hline
\end{tabular}

The average score and the excellence rate (percentage of students obtaining scores above 90 in a 100point test) of the remedial class students is much lower than that of the Class A students in school. Such result suggests that students in the remedial class are not the top students in their schools. The performance of remedial class students is close to the Class B students based on their average score and excellence rate. However, the passing rate of remedial class students is better than that of school's Class B students. The remedial class students also have lower standard deviation compared to that of all three levels of classes in public school. Therefore, we can conclude that the students in remedial class have better consistency in their academic performance. Most of them are above-average students with dedication to elevate their scores into top level through systematic study in remedial classes. The students 
are indeed "capable of understanding physics if they work at it" as described in the survey question of CLASS.

We have communicated with both types of teachers and find that some teachers in public schools make a horizontal comparison of students' academic performance in different subjects. For example, some students may have good grades in chemistry or biology but subpar grades in physics. Then some school teachers may consider that these students as incapable of learning physics. In contrary, teachers in remedial classes pay more attention to the longitudinal changes of students' performance in physics learning. The company cultural and the key performance index (KPI) both required the remedial class teachers to efficiently improve students' achievement in physics. Therefore, the remedial class teachers focus on training students' problem-solving skills, and they are more likely to observe that their students are "capable of understanding physics if they work at it" in a short time.

Moreover, the remedial classes usually have smaller class size than the classes in public schools. According to the feedback of remedial class teachers and public-school teachers, the number of students in a remedial class is usually around 30 and the number of students in a school class is usually about 45 to 50. Compared to the public-school teachers, the remedial class teachers can put more effort and attention to each individual student, especially on those who have difficulties in learning physics.

\subsection{Different curriculum design in public schools and remedial classes}

In real-life teaching activities, the school teachers and remedial class teachers follow different strategies in curriculum design. School teachers often pay more attention to establishing the fundamental concept and principles in class and cultivating students' core literacy on the physics subject. Compared with school teachers, remedial class teachers are more focused on summarizing question types and methods to help students improve problem-solving skills. Below we take "uniform acceleration in onedimension" as an example to observe the different curriculum design on the same content for the two types of teachers.

Through the experiment, the time and speed data of the moving trolley are recorded

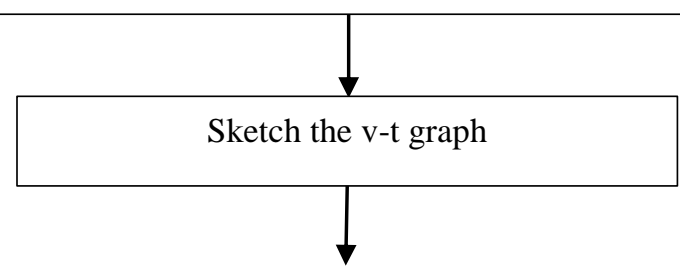

Find a special v-t graph of a straight line with a constant slope

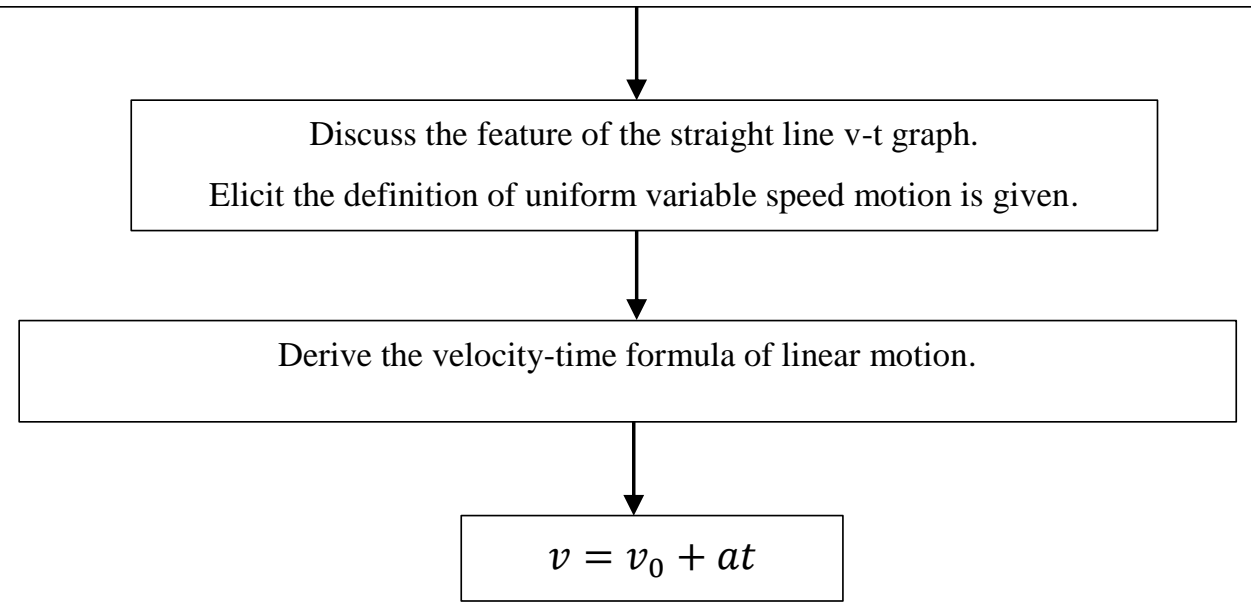

REAL 2021, 6(2) 
Figure 3. School teachers' curriculum design of "uniform acceleration in one dimension"

The curriculum design of school teachers is selected from the official Teachers' Guidance of Physics published by People's Education Press (People's Education Press, Institute of curriculum and teaching materials, Physics Curriculum Textbook R \& D Center, 2010). The course started with an experiment of "the trolley and ticker-timer". By analyzing the paper tape produced by the ticker-timer, the velocity change of the trolley is studied and the v-t graph is drawn. Students can observe multiple line segments in v-t graph, and there is one line with a constant slope among these segments. By analyzing this special segment, the definition and formula of linear motion with uniform variable velocity are derived. The whole process of the course in school is shown in Figure 3.

When remedial class teachers teach the same content of "uniform acceleration in one-dimension", they often omit the experiment and directly start with the definition of uniform acceleration motion. Then they elaborate why uniform acceleration in one dimension can be represented by a straight line of $\mathrm{v}-\mathrm{t}$ graph. The experiment of "trolley and ticker timer" is used as an exercise in problem-solving session of remedial class. The whole process of the course in remedial class is shown in Figure 3.

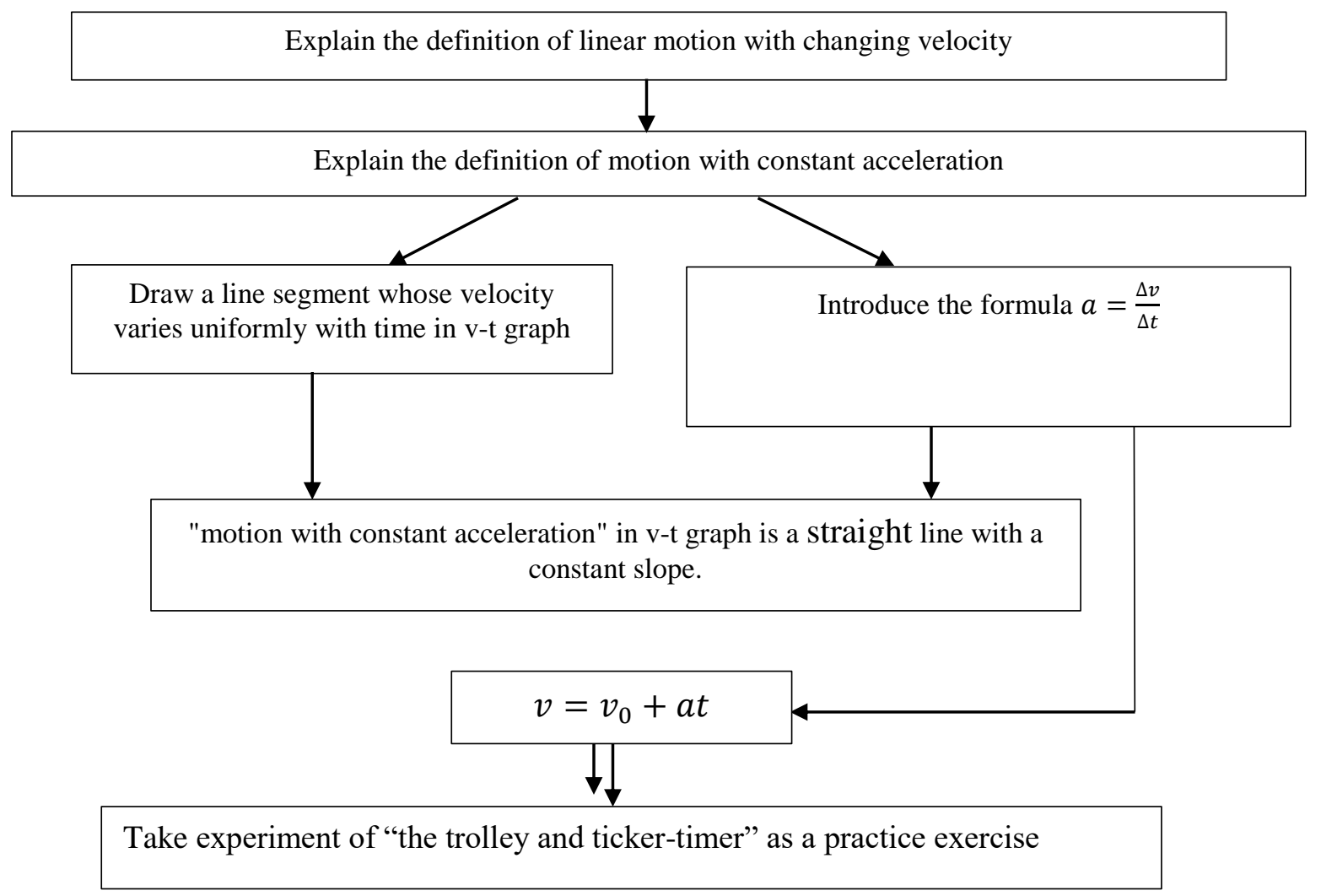

Figure 4. Remedial teachers' curriculum design of "uniform acceleration in one dimension"

When teaching the same content of physics, these two types of teachers choose different ways of building students' knowledge structures. School teachers tend to follow an inductive method to introduce the concept in physics. They start from experiments and try to summarize physical principles from observed phenomena. Remedial class teachers prefer a deductive way in deriving conclusion from fundamental physical principles. They focus more on logical reasoning in order to help students build an 
efficient problem-solving framework. The students in remedial classes can quickly apply what they have learned into problem-solving process, which may enhance the confidence in teaching and learning physics.

\section{Conclusion}

Through the investigation of the attitudes of school teachers and remedial class teachers in physics learning, we find that there is not much overall difference between these two types of teachers' attitudes towards physics learning. The major difference lies in the category of "problem solving confidence". The score of remedial class teachers in this category are higher than that of the school teachers, which is related to the academic background of students and the corresponding curriculum design. In general, school teachers pay more attention to students' core literacy of physics subject and follow an inductive path to construct the physical concepts. Compared with school teachers, remedial class teachers tend to emphasize problem solving and use a deductive way to enhance students' understanding of physical principles.

\section{References:}

Ping Zhang,Weirong Liu,Yanli Li\&Xiaodi Yang (2014). How Free Normal Students' Attitudes and Beliefs about Physics Change- - From First Year University Students to First Two Years of New Teachers. Teacher education research (04), 64-68. (In Chinese)

Fang Fang\&Binlin Zhong (2014). Present situation and countermeasures of private education and training industry in China. Journal of the Chinese Society of Education(05):1-5. (In Chinese)

Yue Gu (2016). Research on Constructing Teacher Competency Model in Training Institutions.Kunming University of Science and Technology(Master Degree). (In Chinese)

Ying Liu (2016). Optimization Study Research on Teacher's Competency of Basic Education Training Institution in Shanghai.East China Normal University(Master Gegree). (In Chinese)

Mirko Marušić \& Josip Sliško (2012). Effects of two different types of physics learning on the results of CLASS test. Physical Review Special Topics. Physics Education Research(1), doi:10.1103/PhysRevSTPER.8.010107.

W. K. Adams,K. K. Perkins,N. S. Podolefsky,... \& C. E. Wieman (2006). New instrument for measuring student beliefs about physics and learning physics: The Colorado Learning Attitudes about Science Survey. Physical Review Special Topics. Physics Education Research(1), doi:10.1103/PhysRevSTPER.2.010101.

People's Education Press, Institute of curriculum and teaching materials, Physics Curriculum Textbook R \& D Center (2010). Teachers' Guidance of Physics.Beijing: People's Education Press. (In Chinese) 